\title{
State-of-the-article
}

\section{Distance learning of foreign languages}

\author{
Cynthia White Massey University, New Zealand \\ c.j.white@massey.ac.nz
}

This article provides a critical overview of the field of distance language learning, challenging the way in which the field is often narrowly conceptualised as the development of technology-mediated language learning opportunities. Early sections focus on issues of concept and definition and both theoretical and pedagogical perspectives on the field. Emphasis is placed on evident shifts from a concern with structural and organisational issues to a focus on transactional issues associated with teaching/learning opportunities within emerging paradigms for distance language learning. The next section reviews choices and challenges in incorporating technology into distance language learning environments, foregrounding decisions about technology made in particular sociocultural contexts, the contribution of 'low-end' technologies and research directions in developing new learning spaces and in using online technologies. The investigation of learner contributions to distance language learning is an important avenue of enquiry in the field, given the preoccupation with technology and virtual learning environments, and this is the subject of section six. The two final sections identify future research directions and provide a series of conclusions about research and practice in distance language learning as technology-mediated interactions increasingly come to influence the way we think about the processes of language learning and teaching.

\section{Introduction}

The last decade has seen a dramatic expansion of distance education with new language learning opportunities being made available to new audiences throughout the world. Many language learners, teachers and researchers have sensed the convenience and potential of new language learning environments in distance education - and in related fields such as online learning, distributed learning and blended learning. Further evidence of the new prominence given to distance language learning and teaching is the sharp rise in the number of publications in the past decade. At the turn of the millennium there was only one edited collection devoted to distance language teaching (Richards \& Roe 1993) whereas in the past five years three book publications have appeared including two edited collections (Henrichsen 2001; Holmberg, Shelley \& White 2005) and one authored

Professor Cynthia J. White, School of Language Studies, Massey University, Private Bag 11 222, Palmerston North, New Zealand. <http://language.massey.ac.nz/staff/CW.shtml> c.j.white@massey.ac.nz book (White 2003). Seminal articles on distance language learning have appeared in TESOL Quarterly, The American Journal of Distance Education, System and ReCALL, and in 2003 special issues of Open Learning and Language Learning and Technology were devoted to languages in distance education.

This article reviews the literature on distance language learning over the past three decades, with most of the focus placed on publications in the last decade. I provide as complete a representation as possible of the literature drawing on key studies as important landmarks in the distance language learning landscape. While a significant body of work has been developed on teacher education at a distance (e.g. Howard \& McGrath 1995; Nunan 1999; Cheng \& Myles 2003) it is not included in this review. Also absent are those studies into networked language learning, tandem learning, blended learning and intercultural communication online situated within face-to-face classroom contexts, since the teachinglearning context differs in significant ways from that of most distance learning environments where the teacher is remote from the many sites of learning of the students, leading to a different range of issues for research and practice. That said, the review makes reference to the wider literature as appropriate, situating developments in distance language learning within the two fields of language teaching and distance education.

In terms of research approaches to exploring distance language learning, there has been a heavy predominance of descriptive studies (e.g. Rothenberg 1998; Rogers \& Wolff 2000), with surveys (Williams \& Sharma 1988; Abrioux 1991), case studies (Crooks \& Lamy 1995; Jennings 1995), pilot studies (Glisan, Dudt \& Howe 1998) and multiple-method qualitative studies (White 1999a) also used in research design. Within the descriptive studies a prominent approach is to describe the process of course development

\footnotetext{
CYNTHIA WHITE is Associate Professor in the School of Language Studies, Massey University, New Zealand. She has published widely on distance and online learning, learner autonomy, learning strategies, and language and settlement issues among migrants and refugees. Her books on languages in distance education are with Cambridge University Press and Multilingual Matters, and in 2006 she edited a special issue of Language Teaching Research on online language teaching.
} 
and decisions about course elements for particular languages: French (Daugherty 1996; Laouénan \& Stacey 1999; Strambi \& Bouvet 2003), Spanish (Glisan et al. 1998; Garrido 2005), German (Shelley 1999; Möllering 2000), Chinese (Hau Yoon 1994), Italian (Strambi \& Bouvet 2003; Tudini 2003, 2005), Arabic (Alosh 2001), and Russian (Stanley, Sutherland \& Valentine 2001). For English the focus has been on Professional English (Curtis, Duchastel \& Radic 1999; Grosse 2001), English for Academic Purposes (Boyle 1994; Catterick 2001; Garing 2002) and more general English courses (Eyring 2001; Ramirez \& Savage 2001; Poon 2003).

Important themes explored in the literature include traditional and emerging paradigms for distance language learning, the development of hybrid learning opportunities, course development and evaluation, teaching roles, learner support, the advent of computer-mediated communication (CMC) and new learning spaces, technology choice in particular sociocultural contexts, and learner contributions to the process of distance language learning, all of which are reviewed here. Throughout the article emphasis is placed on the complexity of distance language learning and teaching given the presence and interplay of human, institutional and sociocultural influences; emphasis is also given to the value of adopting a learner-centred focus in exploring the actual experience and potential of the distance learning of foreign languages.

\section{Paradigms and concepts}

\subsection{Definitions}

Within the distance language literature questions of concept and definition invariably draw on classic definitions within the wider distance education field, focusing almost entirely on organisational or technological concerns rather than pedagogical or human perspectives. It is the definition given by Keegan (1990) which features prominently in the research literature on distance language learning (Boyle 1994; Harrell 1998; Hiple \& Fleming 2002), a definition identifying the following structural features of distance education: the separation of the teacher and learners, the use of technical media, provision of two-way communication, and the influence of an educational organisation, distinguishing it from private study. A different position is advanced by Hiple \& Fleming (2002) where they draw attention to the evolving nature of definitions of distance education and argue that it is two characteristics within Keegan's (1990) definition that distinguish current models for distance language learning: communication must be ELECTRONICALLY BASED and BI-DIRECTIONAL between students and teachers and among students. However the wide range of studies of language learning opportunities published under the rubric of distance education (e.g. Byrnes 1986; Daugherty 1996; Fox 1998; Fleming, Hiple \& Du 2002; Reynard 2003) reveals that, in practice, distance language learning programmes are more varied, more complex and more influenced by human, institutional and sociocultural factors than any definitions suggest. An important challenge for future research is to develop a definition of distance language learning and teaching which can provide an adequate conceptual basis for the field based on a synthesis of perspectives - including those of teachers, researchers and learners - reflecting the complete continuum of practices.

\subsection{Generational models}

The evolution of distance language learning opportunities has largely been in response to developments in technology generally represented in terms of a generational model (see for example Boyle 1995; Wang \& Sun 2001; Poon 2003; Wang 2004a). Different taxonomies have been developed with debates about what exactly constitutes a new generation of learning opportunities. Here I use Wang \& Sun's (2001) four generational model, moving from a first generation of print-based courses as the predominant mode of delivery until the $1970 \mathrm{~s}$ and still in use in many parts of the world, to current fourth generation models using Internet-based real time technology. Between these two landmarks, second generation course models were developed in the 1970s with first broadcast technologies and then audio- and video-based multiple media language courses. The literature of the $1970 \mathrm{~s}$ and $1980 \mathrm{~s}$ includes descriptions of language courses via radio and television (Innes 1982; Byrnes 1986; Kataoka 1987), examples and discussion of materials and techniques (Selman 1988), identification of general issues in distance language teaching (Davies 1977; Holmberg 1985), and surveys of language courses offered through distance education in North America and Australia (Stringer, Shale \& Abrioux 1982; Williams \& Sharma 1988).

Innes (1982) describes the first BBC television language course in German called Kontakte broadcast in 1975 as a milestone in broadcast language teaching. Viewed from today's perspective the course remains highly innovative, combining radio and television broadcasts with support materials, close links with classes throughout the UK, and a final optional achievement test devised and processed by the University of Cambridge Local Examinations Syndicate. The philosophy of open learning, embedded in concerns about social equity, was prominent in discussions at the time especially in relation to those groups previously under-represented in education. As a philosophy this has all but disappeared from current writings, displaced by concerns about access, and interest in lifelong learning (Tuijnman 1999). 
The use of multiple media in second generation courses opened up important lines of investigation into student perceptions and preferences of different learning sources (print, audio, video, broadcast) and the way they function within the students' learning environment (Hagen 1995; White 2000; White, Easton \& Anderson 2000). These research approaches are equally relevant to the investigation of multimodal learning environments.

Subsequent generations use information and communications technology (ICT) and the third generation comprises CD-ROMs (Rothenberg 1998), Web presentation of course materials (Raskin 2001), and asynchronous CMC (Möllering 2000; Stanley et al. 2001). The distinction between using technology to distribute content, and using technology for communication, as in e-mail (Desmarais 1999) and computer conferencing (Lamy \& Goodfellow $1999 b)$, became central to understanding exactly what was being offered by distance online language courses. Concerns about student access to learning environments also emerged at this stage (Poon 2003) and a number of courses offered content in both traditional and online options (Reynard 2003). What has been less evident, however, is research into learner perspectives of what is afforded by ICT-mediated environments and the accessibility of those learning environments.

Closely aligned to asynchronous third generation course models, are those offering interactive synchronous learning opportunities with the instructor and other students, classified by Wang \& Sun (2001) as comprising a fourth generation of distance language learning. Avenues of enquiry that have opened up within synchronous learning include issues of scheduling and access (Fleming et al. 2002), the affordances and constraints of different learning environments (Hampel 2003; Wang 2004a, b), teacher roles (Hampel \& Stickler 2005; Hauck \& Hampel 2005), negotiation using text chat communication tools (Tudini 2005) and defining oral competence online (Lamy 2004). These themes are explored in later sections.

However, the divisions suggested in this section exist more in theory than in practice. All generations of distance language courses remain in use around the world - as correspondence courses, multiple media courses, and ICT-based interactive multimedia courses - as well as in combinations of the above.

\subsection{Traditional and emerging paradigms}

The shifts in distance language education are paralleled by a move within the research literature from a concern with the production and distribution of learning materials, as in broadcast education, to a concern with communication and learning as a social process supported largely by ICT. The shifts in perspectives and practices are best under- stood through Garrison's (2000) distinction between traditional and emerging paradigms in distance education. Traditional paradigms for distance language teaching form much of the literature emphasising independent learning facilitated by self-instructional materials with access to support, feedback and, in some cases, some group learning opportunities. Experience within traditional paradigms for distance language learning and teaching has opened up avenues of research into enhancing progression and persistence and reducing learner isolation (Hau Yoon 1994; Dreyer, Bangeni \& Nel 2005), learner support (Hurd 2001), developing interactive learning opportunities and oral-aural skills (Poon 2003), and course design (O’Dwyer 1993; Garrido 2005), with descriptive studies and case studies as predominant research approaches.

Emerging paradigms for distance learning have developed from the possibility of accessible and sustained opportunities for two-way communication supported by new generations of communications technology, allowing students to collaborate and manage their learning within an interactive environment. This alternative framework has extended enquiry in the field to include teacher roles (Hampel \& Stickler 2005), online tuition (Hauck \& Hampel 2005) and learner response to new learning spaces (White 2003). Murray (2000) notes that while there has been a shift in the positioning of distance education largely due to the advent of CMC, less attention has been paid to the actual effectiveness and outcomes of CMC use compared to earlier forms of distance language programmes. There are now signs that an examination of outcomes for language learning within emerging paradigms of distance education is developing (Hampel 2003; Lamy 2004; Tudini 2005). What is still needed, however, is the development of research tools, methods and approaches appropriate to the new paradigms for distance language learning. Equally important is the development of a research agenda to inform and guide pedagogical practice within rapidly evolving virtual learning environments.

\subsection{Related systems for language learning}

A number of ways of organising language learning have emerged in the past 15 years which can be seen as new hybrids bringing together elements of conventional and distance learning opportunities. These include distributed learning (Hiple \& Fleming 2002; Fleming \& Hiple 2004), hybrid learning (Kym 2004) and blended learning. Important questions remain in terms of how distance language education and related systems may evolve or decline, may converge or diverge, the interrelationships that may develop between them and the ways in which they may affect research and practice in the field of language teaching as a whole. Few critical commentaries 
have appeared addressing these questions, even though there is ample evidence of the prevalence of new learning systems and the eagerness of teachers to adopt them. Of concern too is the quality of some research related to new learning systems, with large numbers of non-peer reviewed articles published on the Web and the appearance of vendor research which has not been independently vetted.

\section{Theoretical perspectives}

Within the field of distance education significant theoretical contributions concern independent study (Wedemeyer 1971), structural models of distance education (Peters 1989), a conversational approach to distance learning and teaching (Holmberg 1989), a theory of pedagogical transactional distance (Moore 1993), and a model of educational transactions at a distance (Garrison 1989). These models reflect the progression of theoretical development in the field of distance education along an organisational (structural) - transactional (teaching and learning) continuum (Garrison 2000). Within the published literature on distance language learning, however, few studies make links to the main theoretical approaches as advanced by Wedemeyer, Holmberg, Peters, Moore and Garrison. They tend instead to draw on research and theoretical frameworks in applied linguistics, in particular on the work of Rod Ellis (e.g. Hampel \& Stickler 2005; Murphy 2005a), David Little (e.g. Harris 2003; Weasenforth, Meloni \& Biesenbach-Lucas 2005) and Mark Warschauer (e.g. Fox 1998; Tudini 2005).

Possible points of intersection between SLA and distance theories as a framework for developing distance language courses have been touched on (Davis 1988; Ariza \& Hancock 2003). Doughty \& Long (2003) for example examine how methodological principles of task-based language teaching can inform choices among a range of technological options available for distance foreign language teaching. An important gap in the research literature appears, however, in extending and elaborating such a synthesis, putting it into practice not only for course design but for sustained course delivery, and then identifying implications for theory, research and practice.

An attempt to develop a theoretical framework for understanding the essentials of distance language learning comes from White (2003) based around the notion of the learner-context interface (White 1999a). The theory is derived from a phenomenographic five-phase study investigating the conceptions students developed in relation to distance language learning. The concept of the interface emphasises distance learning as the relationship and interaction between learner and learning context, rather than the delivery of learning materials. It points to the fact that distance language learning is a highly complex endeavour requiring learners to develop an interface with the learning context that can both guide and be informed by meaningful learning experiences that in fact become the substance of the course for each learner. While there is a widely held view of learners as active within the learning context, it is only recently that we have begun to view them as active in constructing an interface with the distance learning environment. A contribution of the theory is that it moves away from earlier theoretical positions concerned mostly with structural and systems-based issues, focusing instead on how learners establish their learning environment, and negotiate meaning, and come to new understandings in the distance context. In earlier theories too the influence of the individual contexts in which the learning takes place did not figure as a significant variable. White (2005) identifies a number of questions as starting points for further inquiry to advance theory development within the field arguing that theory must be able to inform both research and practice in the broad range of contexts and language learning experiences encompassed by distance education.

Theory-building in distance language learning is still at an embryonic stage and the absence of a central theoretical framework limits the extent to which it is possible to inform, explain and shape new practices. As innovations in technology and practice have clearly outstripped theory development, the use of technology in learning environments has tended to be technology- rather than theory-led (Laurillard 2003). The creation of distance language learning theories that can both inform and explain pedagogical practices within new learning spaces, and the ways in which participants interpret, respond to and shape those practices remains an exciting prospect and challenge.

\section{Pedagogical perspectives}

Pedagogical perspectives on distance language learning have centred around four key themes reviewed here: course development, course evaluation, teaching roles and learner support.

\subsection{Course development}

The perceived centrality of learning resources to distance language learning has meant that much of the research literature has focused on the process of constructing course content. Until the mid1990s, pre-determined content functioned as the main source of instruction, with emphasis on providing an appropriate 'teaching voice' within the materials often through a conversational approach (Holmberg 1989) following distance education principles (Baumann 1999). A detailed account of 
the process of developing a distance language course within this approach is given by Hurd, Beaven \& Ortega (2001), highlighting the stages involved and the way the materials provide both content and support for learning.

There is an evident move within the literature away from a linear course model based on fixed content to an increased focus on fluid course elements which are developed through the contributions and interactions among learners and teachers, and the spoken and written texts they produce. CMC plays a crucial role here, though videoconferencing, interactive television and audioconferencing are other technology-mediated options. Fluid course elements are now a widespread focus of attention because of the possibilities they provide for interaction in the target language (Möllering 2000; Tudini 2003, 2005; Lamy 2005), for collaborative learning opportunities (Raskin 2001; Felix 2002; Lamy \& Hassan 2003), for supporting the learning process and reducing isolation (Shield \& Hewer 1999; Shield, Hauck \& Kötter 2000) and for developing social presence within distance language courses (Grosse 2001). Research exploring how fluid course elements function for language learning and teaching generally draws on discourse analysis and qualitative research tools such as retrospective interviews, e-journals and learning logs.

An important study investigating how students respond to different course development approaches comes from Reynard (2003). Writing from the Canadian context Reynard describes course development for adult migrant distance ESL learners with content made available in two modes: a correspondence program described as a linear-lock-stepped environment, and an online program providing Internet-based open self-selection of all content. Reynard carried out an empirical study with 26 students and their tutors focusing on how students used the activities and resources available to them, whether they demonstrated a preference between linear and online mode, and the nature of teacherstudent communication. Reynard's study is unique in the literature as a detailed comparative study of the choices learners make between online and traditional course design, highlighting significant contextual aspects in the teaching-learning context in interpreting student preference for the online mode, and teacher resistance to the pedagogical shifts required of them in the new learning environment.

While some studies describe course design in relation to particular language skills (Kötter, Shield \& Stevens 1999; Raskin 2001) many more focus on a course design process based around key challenges. Writing from the US tertiary context Weasenforth et al. (2005) identify fostering learner autonomy as a challenge and primary pedagogical objective in developing a course for international students. They describe how three features of course management software - discussion, files and testing features - are used to develop features associated with autonomous learners. In other studies the development of learner autonomy centres on course design which facilitates strategy development, critical reflection and fostering student awareness of their learning (Hurd et al. 2001; Harris 2003; Vanijdee 2003; Hurd 2005). Harris (2003), for example, writing from the context of a European based project, describes the dilemmas faced in designing a handbook for strategy instruction aimed at adult distance learners in a range of countries, at different levels of competence, learning a variety of languages and bringing their own assumptions about the language learning process' (Harris 2003: 17). Murphy (2005b) in a study of distance learners of French, German and Spanish at the Open University UK (OUUK) raises questions about the impact of course design on learner autonomy. She found that while students actively sought out opportunities for meaningful interaction in the target language and exercised a considerable degree of functional control of their learning there was an evident lack of alignment between the nature of the assessment tasks and the goal of developing independent, autonomous learners. More studies are needed following the approach of Murphy (2005b) which explore how distance course design and assessment practices influence the actions learners take and whether pedagogical objectives are met in practice.

Prominent issues identified in the literature on distance language course development include human, logistical and institutional factors. Garing (2002), for example, writing from the context of migrating a face-to-face EAP course to the distance mode traces how budgetary constraints, existing institution-wide IT systems, and organisational change including moves to internationalise education impact on what is possible and what may be expected from a course. An important issue for debate concerns resourcing; getting a course started may be seen as within the abilities and duties of teachers and any additional resourcing needed for course delivery training, course evaluation and course maintenance may be viewed as a cost to be minimised. A significant danger in such an approach is that providers may be under pressure to place more emphasis on individual access to pre-packaged materials and to reduce teacher-student interaction which requires often substantial resources to establish and maintain (Warschauer 2000; Warschauer, Shetzer \& Meloni 2000). We can expect to see more critical commentaries focusing on the impact of institutional agendas on the development and resourcing of distance language courses.

While technology and course content are commonly seen within the literature as the most complex and influential aspects of the course design process, developing knowledge about learners for 
course design, and later for course delivery is equally complex. The challenge inherent in developing awareness of language learners when the teacher is remote from sites of learning has been raised and revisited many times in the research literature (Richards \& Roe 1993; Hau Yoon 1994; Doughty \& Long 2003). Doughty \& Long examine the feasibility of adopting a task-based approach to distance language teaching given that it is based on developing pre-course and ongoing needs analyses as the foundation for syllabus design and pedagogical decisions taken when the course is underway. They argue that course developers need to confront the fundamental question: how can needs analysis be carried out in distance language learning? Approaches discussed in the literature include initial learner profiles (Curtis et al. 1999; Garrido 2005), learning biographies (Grosse 2001), questionnaires (Hau Yoon 1994; Baumann \& Shelley 2003) and open-ended opportunities for students to volunteer personal information in online warm-up activities (Kötter et al. 1999). Despite the usefulness of these approaches, developing adequate methods of needs analysis in distance language teaching remains a key challenge for the field.

\subsection{Course evaluation}

Course evaluation can be seen as related to a call within the broader distance education literature for the development of quality standards which recognise the particular nature of online and online distance courses (Palloff \& Pratt 2001). The complexities and lack of agreement in developing standards for Web-based courses in distance education is in part due to the fact that they are 'complex entities embedded in complex contexts' (Schramm 2005: 232). A further difficulty, echoing earlier points about focus on structural rather than pedagogical issues, is that many of the domains of quality that have evolved as the basis for setting course standards deal with features such as technological infrastructure and institutional commitment rather than the quality of teaching-learning opportunities and relationships in Web-based courses. In the remainder of this section I discuss a landmark study on formative course evaluation (Crooks \& Lamy 1995) and an approach to the evaluation of Web-delivered distance language courses (Fleming et al. 2002).

A formative evaluation cycle combined with a focus on building quality into the teaching/learning process (Thorpe 1993) was the subject of a case study conducted by Crooks \& Lamy (1995) at the OUUK. The design-research-revision stages of the formative evaluation cycle are discussed, involving close collaboration between an educational technologist and the course designers, and eight students who completed the draft French language course. The students worked on the materials in their natural setting - at home - and then provided feedback in three ways: in a group tutorial, in written comments at the end of each unit of work, and in a post-study questionnaire relating to design features of the course and of the support provided. In the decade since the Crooks \& Lamy study student voices in the formative evaluation of distance language courses have been less evident in the research literature, despite moves in other distance language domains to access students' perspectives and experiences (Murphy 2005b; Thang 2005). The Crooks \& Lamy study thus remains an important landmark in the course evaluation literature.

The relationship between pedagogy and technology is central to the detailed course evaluation of Web-delivered distance language courses provided by Fleming et al. (2002). Writing from the University of Hawaii, they provide a careful and sustained rationale for the host of decisions taken in designing, delivering and evaluating distance language programmes for Chinese and Korean, illustrating the close connection between the three processes. Using Riel \& Harasim's (1994) model for networked learning, the courses are evaluated in terms of learning environments, learning experiences, and learning outcomes. Quantitative data was gathered using surveys and qualitative data based on observation, examination of course records and interviews with staff and students. Fleming et al.'s findings support the conception of Web-based language courses as environments for communicative interaction with learners, native speakers and teachers, rather than as environments in which learners primarily interact with online content through selfinstructional modules. They also found that while the course fostered meaningful interactions among participants, a sense of community was less evident as there was no opportunity for this to develop outside of assigned course tasks. An implication is that 'the creation of social spaces within a course has importance that deserves prioritised consideration alongside the design of tasks and activities more directly related to the learning goals of the course' (Fleming et al. 2002: 51). The Fleming et al. study is exemplary in the many lines of enquiry developed to understand and evaluate as fully as possible the actual experience of distance language learning and teaching within a course, and to critically reflect on what is found. While many studies conclude with identified areas for course revision (see for example GermainRutherford \& Halzen 2000), the exploration of that process remains an important gap in the course development literature.

\subsection{Teaching roles}

Teaching roles in distance language learning are markedly different from those required in face-toface classrooms, but have, until recently, received scant attention. In this section I want to focus on 
research into teaching roles once a course is underway, and where the teacher's main function is to establish a personal link with students providing guidance, scaffolding, feedback, assessment and support. In discussing teaching roles most studies refer to tutors, who by definition are not responsible for course design and who have teaching, support and assessment functions.

A major impetus for research into teaching roles came with the development of online distance language learning. Much of the research in this area has been developed by researchers at the OUUK who pioneered the use of audio-graphic computer conferencing in distance language learning. One of the earliest studies focused on tutor perspectives of their role as they worked for the first time within online learning environments providing students with opportunities for oral interaction in the target language using a synchronous Internetbased conferencing system called Lyceum (Hauck \& Haezewindt 1999). One of the challenges the researchers faced was to develop a typology of language tutor roles congruent with online environments. In a subsequent study Shield, Hauck \& Hewer (2001) extend the classification of language tutor roles for online activities required at different course levels within the OUUK. And Hauck \& Hampel (2005) argue that in fulfilling the range of roles required online, flexibility and a shift in mindset are essential qualities for language tutors.

Another research avenue gives attention to the training required to be able to conduct online tutorials. Hampel \& Hauck (2004) analyse tutor response to two kinds of induction sessions in the use of audio-graphic computer conferencing: sessions focusing on using the technology and pedagogical training sessions. The benefits of experiential learning as tutors took on the role of language learners online emerged clearly from the study as well as the dual nature of support required by online language tutors: virtual peer support networks based on sharing responses and experiences with other tutors were as important as sustained access to expert technical and pedagogical support. Hampel \& Stickler (2005) make a further contribution in developing a tutor training framework - for pre-course and ongoing staff development - identifying a pyramid of skills necessary for successful online distance language teaching. What is now needed are further studies testing out how the framework works for tutors training in a range of virtual learning environments and for tutors at different stages of experience.

A third area of research explores the nature of professional practice in distance language teaching, with a focus on the attributes, expertise and e-competencies required of distance language tutors. To investigate this, an unfolding research design was developed with distance language tutors as participants using first focus groups, then questionnaires, and a verbal response procedure called the "yoked subject technique' across three data-gathering phases (White et al. 2005). While the taxonomy of attributes and expertise identified in the first two phases appeared decontextualised and codified, the yoked subject technique allowed the exploration of tutors' personal understandings of particular attributes and expertise, the maxims which underlie them and how they function in practice. The expertise required of distance language teachers is also the focus of a study by Ernest \& Hopkins (2006), considered in terms of ways of encouraging and maintaining innovation. Writing from the Open University of Catalonia, they identify four areas for ongoing online teacher development: developing awareness of the needs of distance learners, encouraging teacher reflection on pedagogical approaches, collaborative construction of knowledge about new pedagogical developments, and promoting a sense of community among distance language teachers.

A major gap in the research remains in relation to the investigation of teacher talk in distance language learning, in spite of Candlin \& Byrnes' (1995) call for attention to this aspect of teaching roles more than a decade ago (see research by Graham (2000) and Joomjaroen (2000) in section 5.2). A small but important investigation of teacher talk online by Lamy \& Goodfellow (1999a, b) opened up this avenue of enquiry as part of a larger study into reflective interaction in web-based conferencing among distance students of French in the Lexica Online project. The contribution of Lamy \& Goodfellow's research is that tutor interactions are examined in the framework of online pedagogy which has reflective interaction as a key component. Two distinct tutor styles are identified and termed the social tutor, who encourages socialisation and places emphasis on the socio-affective needs of students, and the cognitive tutor who is subject knowledge oriented and focuses on syllabus content (Lamy \& Goodfellow 1999b); the most advantageous approach is seen as incorporating both styles. Lamy \& Goodfellow's research has been cited extensively in investigations of distance, online and distributed language learning but few studies have sustained the focus on tutor interactions as they relate to broader issues of online pedagogy.

\subsection{Learner support}

Learner support is an explicit feature of quality distance language education, and involves interaction with learners about their needs, concerns and interests. While much of the published literature focuses on the design and development of distance language courses, a focus on the crucial element of learner support is less evident.

Hurd (2001) provides the earliest overview of research and practice in supporting language learners within distance learning environments, and reports 
on a study exploring the use of support by a random sample of third year distance learners of French at the OUUK $(\mathrm{N}=204)$. Questionnaires were sent to participants at the start of the course, and half-way through, and a focus group procedure $(\mathrm{N}=8)$ was used at the end of the course. Student responses revealed that contact with tutors and attendance at face-to-face study sessions were seen as important contexts for the development of socio-affective dimensions of learner support, to combat isolation, to enhance motivation, and to learn how to approach the assessed components of the course. A noteworthy dimension of Hurd's study is identifying the difficulties students' experienced early on in the course. While a few studies have traced shifts in students' perceptions of their learning process as they progress through a distance language course (see for example White 1999a, 2003), to date an important gap in the literature concerns in-depth study of how learner support requirements develop and change, together with optimal ways of delivering that support at particular stages.

Feedback plays a crucial role in the distance learning process, not only as a way of giving students a response to their performance, but in supporting the learning process, taking an interest in students' learning and providing encouragement. Recent commentaries on providing feedback suggest student needs and learning contexts must be taken into account, and an important role for teachers is to assist students in situating feedback within the framework of experience they have developed about their learning (Ros i Solé \& Truman 2005a, b). A prominent study of feedback came from Hyland's (2001) research at the Open University in Hong Kong, exploring the nature, perceptions and use of feedback given to distance learners of English. Data was gathered through questionnaires $(\mathrm{N}=108)$ and interviews with learners $(\mathrm{N}=10)$ and tutors $(\mathrm{N}=4)$ as well as from feedback given on assignments. Hyland identifies a number of issues for feedback in distance language learning: the possibility and impact of feedback being misunderstood or misinterpreted due to the constraints of distance, the possibility of a mismatch in expectations of feedback between learners and tutors, and the need to examine the kinds of information, support and training given to distance tutors which would guide them in providing more appropriate, effective feedback. The study is noteworthy not only as a detailed investigation of feedback carefully underpinned by the wider research literature, but also because Hyland discusses and interprets the findings with systematic reference to features of the institutional context, learners' individual learning contexts and the perspectives of participants.

Student retention and persistence in distance language courses provide a further dimension to the learner support literature. Writing from the
South Africa context, Dreyer et al. (2005) note that higher education institutions are being confronted with unacceptably high dropout and/or failure rates among distance learners at a time when distance education has been embraced as a means of reaching the new populations for higher education within South Africa. Dreyer et al. propose a proactive approach to learner support beginning with profiling students to determine their strengths, weaknesses and needs, and identifying possible factors that are known to lead to dropout. A strength of the profile is that it takes a contextual approach to understanding individual learners, including elements within the home, institution, work and global environment which may mediate their new role as distance language learners. In addition, the dynamic nature of individual learners and the continuously changing contextual factors which may impact on language learning are recognised within their approach. Given the absence in the literature of longitudinal intervention studies aimed at reducing attrition and enhancing learner support, a subsequent study investigating how the profile is used by teachers and administrators and how it impacts on students' approaches to studying would make an important contribution to the field.

An emerging issue concerning online forms of learner support, in particular the use of CMC, raises questions about how best to provide the kinds of affective and motivational support crucial to distance language learning. ICT presents enormous opportunities to rethink student support in ways that are as yet not fully understood in particular with regard to time and place, and the social dimension of learning which can be enhanced or diminished through CMC' (Tait 2000: 288). Writing from the broader distance education context Blanchfield, Patrick \& Simpson (1999) critically evaluate the use of computer conferencing for guidance and support, and argue that if it is to be judged useful by students it must be appropriate in terms of access, added value, and congruence. The relationship between virtual learner support and aspects of learner identity, the social dimension of learning and possibilities for both peer and individual support remains to be explored in distance language learning.

\section{Technology use: choices and challenges}

Technology - print, audio, video, web, and conferencing - plays a prominent role in any discussion of the development of distance language learning opportunities (Glisan et al. 1998; Rothenberg 1998; Curtis et al. 1999; Möllering 2000; Aderinoye 2005). Research into technology in distance language learning has developed within three broad domains reviewed here: the process of choosing technology in particular sociocultural contexts, the contribution of 'low-end' technologies, and the potential and 
contribution of new learning environments and online technologies.

\subsection{Technology choice in sociocultural context}

Finding the right fit between technology choice, institutional objectives, pedagogical aims and learner needs in particular sociocultural contexts is complex and frequently problematic, and is an important domain for enquiry and reflection. Several studies report on the tensions between technology choice, contextual factors and pedagogical requirements (Evans, Stacey \& Tregenza 2001; Strambi \& Bouvet 2003). Strambi \& Bouvet (2003), for example, discuss the prevailing sense of struggle they experienced between their own vision and needs as language teachers in conceptualising and developing an instructional environment for introductory French and Italian distance courses, and the interests and focus of the IT specialists. From another perspective, Reynard (2003) observes that while initiatives may have institutional support, they may still be met by scepticism and resistance by staff. What would be of particular value to the field would be more longterm studies tracing how such issues and tensions play out, particularly once courses are underway and the needs and requirements of learners become more evident.

Aderinoye (2005), writing from the context of sub-Saharan Africa, notes that much of the current research, writing and theorising in language teaching at a distance assumes access to resources which are not available in many parts of the developing world. He argues that a focus on hi-tech applications is contrary to the spirit of open and distance learning which is concerned to reach the last person in the queue irrespective of their life circumstances. The perspectives advanced by Aderinoye are explored further in the wider distance education literature, though not specifically for languages. Robinson (2001), for example, examines the impact of innovation in distance learning centred on the new technologies and points to the need to understand more fully the contexts of the range of learners who enter distance education and to build better bridges into and out of their learning cultures. And Jegede (2000) draws on his experience of distance education within Africa to critically examine what he describes as the wedlock between technology and distance education. He notes that the drive to use new technologies is often combined with a push to export courses to new, global markets with little, if any, understanding of the learners, their motivations to learn or their socio-cultural environments which may mediate or inhibit learning. The issue of cultural border crossing is developed, as Jegede argues that distance learning environments using the new technologies may require learners to cross many cultural borders for learning to take place, including the culture of the content being learned, the cultural framework through which it is presented, the learner's sociocultural environment, the culture of the use of technology and then of the particular communications technology used in instruction.

More research on the various borders that distance language learners in particular settings and life circumstances are required to navigate to make learning meaningful in their immediate environment is an important avenue for further research. Future studies also need to focus more on exploring elements within the sociocultural context which mediate learning and to demonstrate how these influence technology choice, course design and delivery, student response to different learning sources and the ongoing research-development cycle.

\subsection{Low-technology environments}

A number of studies have documented the process of choosing 'low-end' technologies which fit the needs, life circumstances and learning contexts of their students (Walandouw \& Penrose 1993; Dickey 2001; Ramirez \& Savage 2001; Poon 2003). Walandouw \& Penrose (1993), writing from their experience at the Indonesian Open University, note that while the temptation remains strong for open language learning systems to seek technological solutions, they remain mindful of the low-tech language learning infrastructure available to teachers and students, arguing that advanced technological enhancements to existing print and audio packages would not address bigger challenges relating to the physical and psychological conditions in which their students learn languages, challenges close to issues of student persistence and progression.

The Adult Migrant English Program (AMEP) in Australia has documented and researched the use of the telephone to reach students in remote areas of Australia. From within this context, studies by Graham (2000) and Joomjaroen (2000) are important as examples of teachers' close reflection on their practices relating to low-tech options for teaching conversation at a distance. Noting the fact that telephone conversations with students at a distance can become interrogations, Graham examines transcriptions of three telephone conversations in which she experiments with strategies to make conversations more interactive. Joomjaroen describes the use of audioconferencing with small groups of students, and, like Graham, uses transcriptions to look closely at the role of the teacher in developing discourse with students, and also to see how students cope with longer stretches of conversation and communication breakdown. The two studies are part of a small but significant body of literature revealing processes used by reflective teachers to explore aspects of their practice in distance language learning. 


\subsection{New learning environments and online} technologies

The past two decades have witnessed the development of a range of new distance language learning environments in pilot studies (Goodfellow et al. 1996), as an additional component within second generation course models (Möllering 2000), as alternatives to a more traditional course format (Reynard 2003), and as fully integrated online courses. The growth of access to the Internet in particular has led many distance language educators to rethink the way in which they provide tuition; so much of this section will concern online technologies. Earlier developments, however, came with the advent of videoconferencing and interactive television, and these are also reviewed, as well as the use of computer conferencing and course management software. In this section I emphasise the different research angles developed to explore new environments for distance language learning.

It is commonly asserted that videoconferencing has an immediate and beneficial application to language learning because it provides face-to-face communication at a distance (Nicholson 1997; Laouénan \& Stacey 1999; Wang \& Sun 2000; Wang 2004a, b). Research into videoconferencing in distance language courses has revealed a range of possible benefits - principally increased learner confidence and motivation - alongside challenges posed for teaching and learning. Key among these challenges is the impact on the language produced, on interpersonal dynamics, and learning and teaching strategies (Laouénan \& Stacey 1999; Wang 2004a, b). One of the earliest and most detailed studies was carried out by Goodfellow et al. (1996) based on pilot videoconferencing tutorials as part of a distance learning component of a Professional English course. While they found evidence for the considerable motivational benefit of videoconferencing for participants, they also found certain types of tutorial activity such as individual correction, reflection on learning and management of group discussion were not well supported by the technology. Goodfellow et al.'s conclusion about the value of videoconferencing in mainstream distance delivery namely that the costs remain high and course providers need to be aware of additional 'pedagogical overheads' such as the rethinking of teaching approaches and the preparation of material - has both been echoed (Hampel \& Baber 2003) and contested (Wang 2004a, b) in later studies. In an empirical study of videoconferencing with eight distance language learners of Chinese over 34 sessions, Wang (2004b) explores the capabilities of the videoconferencing tool NetMeeting and participants' perceptions of the new learning environment; the instruments used to evaluate Net Meeting together with extensive comments from participants are provided. An important contribution of the study is the identification of specific pedagogical issues which need further investigation including videoconferencing-based task design and the positive impact of the video and videoconferencing on distance language learners' confidence building and acquisition of communicative competence. While videoconferencing has been trialled in a number of studies, as yet little progress has been made in incorporating it into mainstream distance language courses.

The process of including complex technology in mainstream settings has been explored in terms of interactive television (ITV) as a feature of mostly US and Australian distance education systems. Writing from the Australian context Evans et al. (2001) employ a case study approach to provide a detailed tracing of the way ITV was conceptualised as providing instruction for foreign languages in schools, how it evolved and then receded into something far removed from the original conception. In their discussion of tensions surrounding the introduction of educational technology and change, they identify two critical issues: firstly, course development was separated from the contexts of delivery, so teachers had little control over the content and rate of progression within the broadcasts, meaning that students were less able to sustain participation; secondly, to cut costs and to overcome scheduling difficulties the interactive elements were scaled down, then removed and student motivation declined. This research illustrates that technology use is never inconsequential and is often a high-stakes innovation in terms of costs, human resources and expectations involved. More long-term studies are needed following how technology is introduced into particular settings, how it relates to existing practices and the course of change around how it is used.

The advent of the Internet and $\mathrm{CMC}$ has provided new possibilities for addressing the issue of interactive competence in distance language learning. An important discussion of this was first developed by Kötter (2001), analysing two pilot studies carried out at the OUUK into opportunities for spontaneous interaction and collaborative learning activities using Internet-based audio conferencing in real time. In terms of the development of interactive competence, Kötter et al. (1999) and Kötter (2001) note that learners became increasingly aware of the gaps in their current level of competence in the foreign language and they received a substantial amount of collaborative support from other students in interacting in the TL, but that learners with basic or intermediate competence in the TL required more tutorial support than anticipated. As the first wave of studies to focus explicitly on the development of interactive competence online using synchronous audio, these studies broke new ground in exploring how and to what effect different teaching strategies, 
learning opportunities and online tools promote interactive competence for distance language learners.

At the same time an important body of work on reflective interaction was developing, exploring the ways in which reflection can be optimally combined with interaction in asynchronous textbased computer conferencing (Goodfellow \& Lamy 1998; Goodfellow et al. 1999; Lamy \& Goodfellow 1999a, b). On the basis of these studies a preliminary tripartite model of message types within CMC was developed together with distinctive features of each message type. An important conclusion was that students' response to and participation in text-based CMC learning environments was less straightforward than had been assumed. The relationship between task type and reflective interaction was the next avenue of research carried out over 15 months of 'peer learning' among four distance students of French (Lamy \& Hassan 2003). Findings suggest that while explicitness in task presentation is all important in persuading distance learners to undertake solo or interactive reflective work 'instructor-led or materials-led facilitation of reflection plays only a small part in the promotion of reflective habits' (Lamy \& Hassan 2003: 55). They suggest that designers of online tasks might encourage reflection by creating a psychological and conversational space in which learners can be responsible for task management and share reflections with peers, arguing that more research is needed into the kinds of psychological and socio-cultural factors which are influential determinants in the uptake of reflective strategies. The methodologies used in the series of studies by Lamy and co-researchers have drawn on discourse analysis of interactions and reflective commentaries, observation and interviews. Future studies can look to stimulated recall with learners and research tools associated with sociocultural approaches to understanding language learning and teaching in investigating reflective interaction in particular online settings.

A new avenue of research is opened by Lamy (2004) as she turns attention to the question of what constitutes oral competence in synchronous environments. In exploring the parameters for addressing that question, Lamy highlights the methodological challenges in analysing the oral competence of distance foreign language students of French using synchronous voice tools at the intermediate level. Three key difficulties concern choosing the type of evidence used to claim oral competence for an individual, deciding how to interpret the evidence, and deciding how to represent conversational competence exhibited by the group rather than an individual. There is a need to extend this line of enquiry to include other synchronous learning environments, particularly in cases where contributions are used for assessment purposes.
The usefulness of chatlines as a pedagogical tool for elementary distance learners is a developing area of research for learners of Italian (Tudini 2005) and Spanish (Blake 2005). The study reported by Blake explores how CMC can be used with beginners in the Spanish without walls program offered by the University of California, Davis, and the effect of chat tools which have a sound exchange option. Blake argues that weekly bimodal (i.e. oral and written) CMC provides the essential 'glue' for language learning at a distance; CMC engages students, allows them to bring alive the language they study independently during the week and helps maintain motivation. An important aspect of Blake's work involves pointing to effects of the written language as the primary mode of instruction in distance language courses.

There has also been greater use of the new technologies within distance language learning for authentic encounters with the target language and culture. Tudini (2003) extends the integration of CMC tools into distance language courses to include public native speaker chat rooms as a pedagogical tool for intermediate distance learners of Italian. The learners in her study interacted in dyads with native speakers in a Web-based Italian native speaker chat program C6 without teacher intervention. Tudini found learners frequently negotiated with native speakers in the open-ended tasks, and that chat discourse appeared to promote learner noticing of errors and attention to form. An important conclusion from the study is that virtual chatting with native speakers provides 'an authentic and purposeful cross-cultural experience which is otherwise limited to the language teacher, members of the local community or other learners' (Tudini 2003: 157). Tudini notes that more research is needed as to whether efforts to improve conversational skills translate from the chat $\log$ to spoken interaction. Looking to the broader literature on intercultural computer conferencing exchanges (e.g. Kramsch \& Thorne 2002), an important direction for research among distance learners concerns issues of pragmatic and intercultural competence in virtual interactions with native speakers and in telecollaborative exchanges between language learners in different countries (Kern, Ware \& Warschauer 2004; O’Dowd \& Ritter 2006). The challenge will be to link exposure to the target language use in authentic contexts to instruction, and to other forms of pedagogical support within the course. The extensive literature and diverse research directions developed for tandem learning (e.g. Lewis 2003; Little 2003; Otto 2003; Stickler 2004) could be used to inform this emerging research agenda.

A key issue in introducing online technologies in distance language learning is the process of developmental testing, and how it affects online tuition, task design, tutor training and student support, 
together with changes in online tools (Hampel 2003). One example comes from Ros i Solé \& Mardomingo (2004) who describe the development of Trayectorias, a web quest which includes a number of scaffolding and modelling features to guide distance students in online task-based learning. The article describes the development of the first version of Trayectorias, a first pilot study, the refinement of the tool, and then a small-scale trial using the new version with a cohort of students $(\mathrm{N}=23)$. Questionnaires were used to explore students' perceptions of the online task within Trayectorias and the written texts students' produced were analysed to determine the degree of personal involvement in the task. The study is important as an example of the ongoing refinement of a web tool, including close analysis of how students respond to particular problem solving tasks.

The place of course management software (CMS) in developing distance language learning environments is contested in the literature. A number of reports outline the ways in which course management software fulfils important functions, particularly within distributed learning environments (Catterick 2001; Weasenforth et al. 2005). Elsewhere attention is focused on the distinct pedagogical needs of distance language education and the way they are not readily met by generic course management templates (Fleming et al. 2002; Doughty \& Long 2003). A particular concern is that language teachers may allow the available tools to dictate choices about how instruction will take place rather than technology being required to serve pedagogy. Part of the difficulty is that while online technologies have improved in quality and power, the same cannot be said about online pedagogies. To meet this challenge, collaborative action research is a promising research approach, allowing teachers and researchers to explore and extend pedagogical knowledge and skills in online tuition.

The focus of research directions in online distance learning environments intersects with research interests in networked language learning (Kern \& Warschauer 2000; Felix 2002). The context of delivery is, however, very different and a different hierarchy of issues emerges. Particular challenges include the fact that the teacher is not physically present to assist and orient learners to using the learning environment, and challenges relating to maintaining motivation and participation are more difficult to address at a distance. An important aspect of evaluating new learning spaces in distance language learning concerns the demands and opportunities of those environments from the learners' point of view (White 2003). A critical commentary on the impact of new technologies on students within open and distance learning is provided by Thorpe (2001), who argues that when learning technologies are added to the resource base of learning programs, they may increase the study time required and learning demands as students must expend time and effort figuring out what each medium carries and how best to use it. Kötter (2001), for example, notes that in an audioconferencing pilot the single most important factor accounting for student dropout was time as students perceived the time commitment to be too great in addition to other course work. A key issue then is the degree to which online environments are integrated into course aims and objectives, and, more importantly, are perceived as such by students. Further research into the demands and opportunities of new distance language learning environments needs to take into account the issues of time and time pressures for learners, and to consider the effects of more complex and more varied learning sources particularly in open distance language learning.

\section{Learner contributions}

An important body of research concerns what Breen (2001) terms LEARNER CONTRIBUTIONS to distance language learning, exploring what learners bring to the process and how that changes as their experience develops within the new learning environment. Within this domain, studies have investigated learner affect and self-management (Harris 1995; Hauck \& Hurd 2005), learner expectations and beliefs (White 1997, 1999a), metacognitive knowledge (White 1999b) and strategy use (Oxford et al. 1993; Harris 1995; White 1995, 1997; Hauck \& Hurd 2005). Much of this research has highlighted the dynamic nature of learner attributes, conceptualisations and affects in distance language learning. Harris (1995), for example, interviewed 12 adult distance learners of English in the AMEP to find out what to them constituted successful learning at a distance, and how they attempted to manage their learning to approximate those successful learning experiences. The students voiced their ongoing struggle within three domains identified as academic inhibition, practical inhibition and affective inhibition, and ways of overcoming these inhibiting factors. Harris' study is noteworthy as one of the earliest examples of qualitative research into the experience of distance language learning, representing the ways in which students voiced the realities of learning within their individual contexts and life circumstances.

A contextual approach to exploring expectations and emergent beliefs of distance language learners has offered some insights into the dynamics of learner experiences and beliefs in an unfamiliar environment for language learning. White (1999a) tracked the expectations, shifts in expectations and the emergent beliefs of novice distance language learners through a longitudinal five phase study using an iterative data collection cycle of interviews, questionnaires, scenario tasks and yoked subject procedures. Reports revealed for the majority of learners a shift from external to internal locus of control, different 
levels of tolerance of ambiguity and a predominant conception of distance language learning as involving the construction of a learner-context interface. Extensions of the study (White 2003) showed how the same students in subsequent semesters continued to engage with ongoing environmental restructuring and the internal restructuring of their expectations and beliefs, in order to develop and maintain optimal learning conditions. A more contextualised approach to understanding distance language learning is difficult to develop and research, since many aspects of the learning context are remote and individual, but this remains a valuable approach in developing insights into the experience of distance language learning.

Hauck \& Hurd (2005) report on two longitudinal studies using questionnaires and interviews to explore language anxiety in distance language learning and the strategies deployed to deal with this in both faceto-face and online tutorial contexts. They conclude that self-management strategies contribute to an increase in learners' self- and contextual knowledge which can assist in reducing anxiety. A contribution of the study is that it explores the kinds of anxiety that can arise within multimodal virtual learning spaces, especially in relation to the variety and simultaneity of modes available, and the extra dimension this adds to the need for learner self-management.

In these studies we have a picture of distance language learners developing knowledge of themselves, their learning processes and the possibilities within their immediate environment as they seek to integrate their characteristics, needs and circumstances with the affordances of the distance learning context. More research is needed into the ways in which individual learners make the crucial step of developing a sense of their identity as distance language learners and a sense of congruence and affiliation with increasingly diverse and complex distance environments for language learning. More research is also required into individual variables in distance language learning, such as motivation, which would further our understanding of distance language learning and of second language acquisition processes.

\section{Future research}

This review has charted three decades of research into distance language learning and I now turn to an examination of emerging research directions and new lines of enquiry in the field.

\subsection{Evaluation of new learning spaces}

As technologies provide increasingly sophisticated arenas for distance language learning, the search for appropriate research paradigms is ongoing. There is an evident need for rigorous studies into learning outcomes within new learning spaces, and for perspectives and research approaches that can guide in the development and evaluation of new learning environments and the pedagogies used within those environments. A related challenge for research is to provide an understanding of the opportunities and limitations of pedagogical approaches in distance language teaching with a variety of technologies, and in particular combinations of technologies and approaches. There is also a need for more studies focusing on technology not as a single tool but as a support for the total environment of learning. Issues of congruence are critical here too; the potentialities of the new learning spaces are totally dependent on the congruence between different course elements, the kinds of activities which are devised, the skills of the teacher and, most importantly, the overall quality of support within the context of delivery. Exploring the nature of such congruence, and how it develops, is a critical and fascinating area for research, and is strongly related to broader questions about the need to explore the articulation of new learning environments into more traditional course formats and how these relate to course curricula and pedagogical aims.

\subsection{Innovation}

The innovations reported in the literature owe much to the work of early adopters - who pursue those innovations, usually in small-scale pilot studies, find ways through the barriers that emerge, and report their findings. An important area for enquiry and critical reflection concerns the process of migrating these innovations to contexts for mainstream course delivery. This must be seen in the light of existing tensions within the field, most crucially between those who emphasise technological innovation as the route to take, those who see pedagogical innovation as the challenge, and those who focus on the learners and ways of enhancing the quality of their learning experiences, given such issues as access, resources, and learner preferences. There is an urgent need for research which accommodates all concerns a concern for innovation and enhanced learning experiences, informed by an understanding of the realities of distance study for the many different learners who enter distance language programs.

\subsection{Hybrid language learning environments}

The rapid emergence of blended, distributed and other hybrid learning environments means that the boundaries between distance education and conventional education are fading, as more and more teachers move parts of their curriculum and learning tasks to the Web. A crucial avenue for research concerns how students work within distributed learning environments, comprising typically classroom 
instruction, independent learning and online learning environments, both individual and collaborative. How students perceive the affordances of the different environments, and how they contribute to developing a productive interface across different learning contexts is another fascinating domain for future research. Within the distance language learning literature there are important precedents and underpinnings for this area of enquiry.

\subsection{Less commonly taught languages}

The growing and changing needs for foreign language competence, especially in less-commonly taught languages (LCTLs), have prompted the development of distance language learning opportunities, particularly in the US context. This remains, however, an under researched area. While some literature has been developed on the distance teaching of Chinese and Japanese much less is available for Russian, Korean and Arabic for example. Important research directions include how individual technologies can facilitate the acquisition of literacy, particularly in languages with non-Roman scripts, and the use of new technologies for proficiency testing, given that university or external funders have a strong interest in seeing the impact of their investment in terms of language performance. There is also a need for more research into the development of interactive competence and intercultural communicative competence among distance learners of LCTLs and optimal ways of acquiring that competence. A recent innovation in the US context is the Arabic without walls project, developed by the University of California and the National Middle East Language Resource Centre, a distance language programme with emphasis on providing authentic materials and online tasks to supplement a widely used textbook. Since the project aims to make learning Arabic accessible to a very wide audience, ranging from high-school students to senior citizens, research into how students respond to the range of learning opportunities in the course and the kinds of support they require at particular stages of the programme are two critical areas for investigation. For the field of distance learning for LCTLs to advance we need more long-term studies of the ways in which language courses are developed, evaluated and revised as they are used with different groups of learners and extended to intermediate and advanced proficiency levels.

\subsection{Development of intercultural competence}

Within the European context an emerging body of research explores the aspect of intercultural competence gain among distance language students (Baumann \& Shelley 2003; Fay \& Davcheva 2005;
Garrido 2005; Shelley \& Baumann 2005) and the extent to which materials and pedagogy in distance language courses enable students to engage critically with issues of racism, identity, culture and human rights (Osler \& Starkey 2001). Investigation of the acquisition of intercultural competence has been carried out using questionnaires (Baumann \& Shelley 2003), case studies and analysis of course work (Shelley \& Baumann 2005) with portfolio assessment also identified as a promising tool for exploring this aspect of language learning (Garrido 2005). A key avenue for future research is to examine and refine more fine-grained approaches to tracking how intercultural competence is enhanced and develops for distance learners in particular contexts including within distance courses adopting a reflective cultural approach from beginners' level (Ros i Solé 2003). The contribution of telecollaborative language study to the development of intercultural competence among distance learners is an avenue ripe for exploration.

\section{Conclusion}

Research on distance language education is now entering its fourth decade. Significant change has taken place in the last decade and this looks likely to continue, with a focus in many quarters shifting away from the delivery of content to facilitating transactions between learners, teachers and native speakers. The ideal of the independent language learner remains an important conceptual marker in the field, but it is being rapidly replaced by the ideal of a collaborative learning community where learners find support for and develop control of their learning in interactions and exchanges with peers, learners, teachers and native speakers. In a recent metaanalytical study of research in distance education, the year 1998 is posited as a turning point in research and practice with the dramatic growth of the World Wide Web and Internet-based technologies and maturation of distance education programmes with more powerful delivery media and more sophisticated support systems (Zhao et al. 2005). There are signs too of a growing interplay between research and practice in the field, and there is clear evidence of continuity and refinement of research domains particularly in terms of synchronous and asynchronous learning environments, interactive competence, online tuition, learner autonomy and critical commentaries on developments within the field.

Rapid changes raise important issues of access and quality in the provision of distance language learning opportunities by small providers as well as mass providers, with issues of scale impacting on quality. Looking ahead, it is possible that the small providers could rapidly become the elite providers, working in small-scale contexts with select groups with access 
to well-developed support systems. Providing highquality distance language learning opportunities for all learners is still a key challenge for the field, and whether providers meet this challenge successfully, particularly in the global context, remains to be seen. Research has a crucial role to play in the viability of this position.

New providers and learners will continue to be drawn to the promise of technology-mediated distance education, even in the face of cautions about the overselling of technology and of the relatively slow learner acceptance of some of the new learning spaces. This is a fundamental paradox related to emerging paradigms for distance language learning which is likely, in time, to become even more acute. The challenge for research is to provide an understanding of the opportunities and limitations of pedagogical approaches within different learning environments, and the affordances of those environments from learners' perspectives. Not only would this advance our understanding of the distance learning of languages, it would also clarify important issues for the wider field of language teaching, as technology-mediated learning environments come to figure increasingly in language instruction.

\section{References}

Abrioux, D. (1991). Computer-assisted language learning at a distance: An international survey. The American Journal of Distance Education 5.1, 3-14.

Aderinoye, R. (2005). Distance education and languages: Evolution and change [Review]. The International Review of Research in Open and Distance Learning 6.3. <http://www. irrodl.org/index.php/irrodl/article/view/269/443> accessed 5/7/2006.

Alosh, M. (2001). Learning language at a distance: An Arabic initiative. Foreign Language Annals 34.4, 347-354.

Ariza, E. \& S. Hancock (2003). Second language acquisition theories as a framework for creating distance learning courses. International Review of Research in Open and Distance Learning 4.2. <http://www.irrodl.org/index. php/irrodl/article/view/142/222> accessed 5/7/2006.

Baumann, U. (1999). Deutsch im Fernstudium an der Open University. Zeitschrift für interkulturellen Fremdsprachenunterricht 4.1. <http://www.spz.tu-darmstadt.de/ projekt_ejournal/jg_04_1/beitrag/baumann1.htm> accessed $\overline{5} / 7 / 2006$.

Baumann, U. \& M. Shelley (2003). Adult learners of German at the Open University: Their knowledge of and attitudes towards Germany. Open Learning 18.1, 61-74.

Blake, R. J. (2005). Bimodal CMC: The glue of language learning at a distance. CALICO Journal 22.3, 497-511.

Blanchfield, L., I. Patrick \& O. Simpson (1999). Computer conferencing for guidance and support. British Journal of Educational Technology 31.4, 295-306.

Boyle, R. (1994). ESP and distance learning. English for Specific Purposes 13.2, 115-128.

Boyle, R. (1995). Language teaching at a distance: From the first generation model to the third. System 23.3, 283-294.

Breen, M. (ed.) (2001). Learner contributions to language learning: New directions in research. Harlow, England: Longman.

Byrnes, F. (1986). 'Hello Australia': ESL by TV. Prospect 1.3, $55-63$.
Candlin, C. \& F. Byrnes (1995). Designing for open language learning - Teaching roles and learning strategies. In S. Gollin (ed.), Language in distance education: How far can we go? Proceedings of the NCELTR conference. Sydney: NCELTR, 126-141.

Catterick, D. (2001). An academic writing course in cyberspace. In Henrichsen (ed.), 83-94.

Cheng, L. \& J. Myles (2003). On-line challenges facing inservice teacher education courses in teaching English as a second language. Open Learning 18.1, 29-38.

Crooks, B. \& M.-N. Lamy (1995). Using combinations of video, audio and print to teach French at a distance: A case study of the formative evaluation cycle. European Journal of Psychology of Education 10.2, 131-144.

Curtis, S., J. Duchastel \& N. Radic (1999). Proposal for an online language course. ReCALL 11.2, 38-45.

Daugherty, J. (1996). Development and testing of a CALL program to teach indirect speech in French in a distance learning environment. Computer Assisted Language Learning 9.2-3, 281-290.

Davies, N. (1977). Language teaching at a distance: A challenge to the university department. IRAL 15.3, 239245.

Davis, J. (1988). Distance education and foreign language education: Towards a coherent approach. Foreign Language Annals 21.6, 547-550.

Desmarais, L. (1999). Le courrier électronique: un outil d'enseignement en milieu de travail. Computer Assisted Language Learning 12.4, 323-344.

Dickey, R. J. (2001). Make it a conference call: An English conversation course by telephone in South Korea. In Henrichsen (ed.), 51-60.

Doughty, C. \& M. Long (2003). Optimal psycholinguistic environments for distance foreign language learning. Language Learning and Technology 7.3, 50-80.

Dreyer, C., N. Bangeni \& C. Nel (2005). A framework for supporting students studying English via a mixed-mode delivery system. In Holmberg et al. (eds.), 92-118.

Ernest, P. \& J. Hopkins (2006). Coordination and teacher development in an online learning environment. CALICO Journal 23.3, 551-568.

Evans, T., E. Stacey \& K. Tregenza (2001). Interactive television in schools: An Australian study of the tensions of educational technology and change. International Review of Research in Open and Distance Learning 2.1. <http://www. irrodl.org/index.php/irrodl/article/view/31/83> accessed $5 / 7 / 2006$.

Eyring, J. (2001). Technology with a human touch: Reaching ESL students in their own communities through interactive television. In Henrichsen (ed.), 13-24.

Fay, R. \& L. Davcheva (2005). Developing professional intercultural communicative competence: Reflections on distance learning programmes for language educators and translators/interpreters in Bulgaria. In Holmberg et al. (eds.), 140-165.

Felix, U. (2002). The web as vehicle for constructivist approaches in language teaching. ReCALL 14.1, 2-16.

Felix, U. (ed.) (2003). Language learning online: Towards best practice. Lisse, Netherlands: Swets \& Zeitlinger.

Fleming, S. \& D. Hiple (2004). Distance education to distributed learning: Multiple formats and technologies in language instruction. CALICO Journal 22.1, 63-82.

Fleming, S., D. Hiple \& Y. Du (2002). Foreign language distance education: The University of Hawaii experience. In C. Spreen (ed.), 13-54.

Fox, M. (1998). Breaking down the barriers: Perceptions and practice in technology-mediated distance language acquisition. ReCALL 10.1, 59-67.

Garing, P. (2002). Adapting and developing e-learning courses: The challenge of keeping the quality. Wellington, New Zealand. In Evolving e-learning. Conference proceedings 
Distance Education Association of New Zealand. Wellington: DEANZ Association.

Garrido, C. (2005). Course design for the distance learner of Spanish: More challenges than meet the eye. In Holmberg et al. (eds.), 178-194.

Garrison, D. (1989). Understanding distance education: A framework for the future. London: Routledge.

Garrison, D. (2000). Theoretical challenges for distance education in the 21st century: A shift from structural to transactional issues. International Review of Research in Open and Distance Learning 1.1. <http://www.irrodl.org/index. $\mathrm{php} / \mathrm{irrodl} /$ article/view/2/333> accessed 5/7/2006.

Germain-Rutherford, A. \& N. Halzen (2000). Collaborative distance learning for advanced French oral proficiency in professional contexts. In Distance Learning 2000: Proceedings of the Annual Conference on Distance Teaching $\mathcal{E}$ Learning, Madison, Wisconsin. Madison, WI: University of Wisconsin-Madison, 165-172.

Glisan, E., K. Dudt \& M. Howe (1998). Teaching Spanish through distance education: Implications of a pilot study. Foreign Language Annals 31.1, 48-66.

Goodfellow, R., I. Jeffreys, T. Miles \& T. Shirra (1996). Face-to-face language at a distance? A study of a videoconferencing try-out. ReCALL 8.2, 5-16.

Goodfellow, R. \& M.-N. Lamy (1998). Learning to learn a language at home and on the Web. ReCALL 10.1, 6878.

Goodfellow, R., P. Manning \& M.-N. Lamy (1999). Building an online open and distance language learning environment. In R. Debski \& M. Levy (eds.), Worldcall: Global Perspectives on Computer-Assisted Language Learning. Exton, PA: Swets and Zeitlinger, 267-285.

Graham, J. (2000). Casual conversation at a distance. In H. d. S. Joyce (ed.), Teachers' voices 6: Teaching casual conversation. Sydney: NCELTR, 63-70.

Grosse, C. U. (2001). 'Show the Baby', the Wave, and 1000 thanks: Three reasons to teach via satellite television and the Internet. In Henrichsen (ed.), 39-50.

Hagen, S. (1995). User preferences in open and distance language learning: What are the options for multimedia? ReCALL 7.1, 20-25.

Hampel, R. (2003). Theoretical perspectives and new practices in audio-graphic conferencing for language learning. ReCALL 15.1, 21-36.

Hampel, R. \& E. Baber (2003). Using Internet-based audiographic and video conferencing for language teaching and learning. In Felix (ed.), 171-191.

Hampel, R. \& M. Hauck (2004). Towards an effective use of audio conferencing in distance language courses. Language Learning and Technology 8.1, 66-82.

Hampel, R. \& U. Stickler (2005). New skills for new classrooms: Training tutors to teach languages online. Computer Assisted Language Learning 18.4, 311-326.

Harrell, W. (1998). Language learning at a distance via computer. International Journal of Instructional Media 26.3, 267-281.

Harris, C. (1995). 'What do the learners think?': A study of how It's Over To You learners define successful learning at a distance. In S. Gollin (ed.), Language in Distance Education: How far can we go? Proceedings of the NCELTR Conference. Sydney: NCELTR, 44-54.

Harris, V. (2003). Adapting classroom-based strategy instruction to a distance learning context. Tesl-EJ 7.2. <http://cwp60.berkeley.edu:16080/TESL-EJ/ej26/ a1.html $>$ accessed 5/7/2006.

Hau Yoon, L. (1994). The development of a self-study Mandarin Chinese language course for distance learners at the University of South Africa. Progressio 16.1, 70-80.

Hauck, M. \& B. Haezewindt (1999). Adding a new perspective to distance (language) learning and teaching - the tutor's perspective. ReCALL 11.2, 46-54.
Hauck, M. \& R. Hampel (2005). The challenges of implementing online tuition in distance language courses: Task design and tutor role. In Holmberg et al. (eds.), 258-277.

Hauck, M. \& S. Hurd (2005). Exploring the link between language anxiety and learner self-management in open language learning contexts. European Journal of Open, Distance and E-learning 2005/II. <http://www.eurodl.org/ materials/contrib/2005/Mirjam_Hauck.htm> accessed $5 / 7 / 2006$

Henrichsen, L. (ed.) (2001). Distance-learning programs. Alexandria, VI: TESOL Inc.

Hiple, D. \& S. Fleming (2002). Models for distance education in critical languages. In Spreen (ed.), 1-12.

Holmberg, B. (1985). Teaching foreign languages at a distance. Distance Education 6.1, 79-90.

Holmberg, B. (1989). Theory and practice of distance education. London: Routledge.

Holmberg, B., M. Shelley \& C. White (eds.) (2005). Distance education and languages: Evolution and change. Clevedon: Multilingual Matters.

Howard, R. \& I. McGrath (eds.) (1995). Distance education for language teachers. Bristol, PA: Multilingual Matters.

Hurd, S. (2001). Managing and supporting language learners in open and distance learning environments. In $\mathrm{M}$. Mozzon-McPherson \& R. Vismans (eds.), Beyond language teaching towards language advising. London: CILT, 135-148.

Hurd, S. (2005). Autonomy and the distance language learner. In Holmberg et al. (eds.), 1-19.

Hurd, S., T. Beaven \& A. Ortega (2001). Developing autonomy in a distance language learning context: Issues and dilemmas for course writers. System 29.3, 341-355.

Hyland, F. (2001). Providing effective support: Investigating feedback to distance language learners. Open Learning 16.3, 233-247.

Innes, S. (1982). Teaching languages through the BBC. Teaching at a Distance 21. 56-59.

Jegede, O. (2000). The wedlock between technology and open and distance education. In T. Evans \& D. Nation (eds.), Changing university teaching: Reflections on creating educational technologies. London: Kogan Page, 45-55.

Jennings, C. (1995). Enriching the distance language learning experience through telematics and multimedia: A case study. ReCALL 7.1, 26-33.

Joomjaroen, L. (2000). Teaching casual conversation at a distance: The challenges. In H. d. S. Joyce (ed.), Teachers' voices 6: Teaching casual conversation. Sydney: NCELTR, 7185.

Kataoka, H. (1987). Long distance language learning: The second year of televised Japanese. Journal of Educational Techniques and Technologies 20.2, 43-50.

Keegan, D. (1990). Foundations of distance education (2nd edn.). London: Routledge.

Kern, R., P. Ware \& M. Warschauer (2004). Crossing frontiers: New directions in online pedagogy and research. Annual Review of Applied Linguistics 24. 243-260.

Kern, R. \& M. Warschauer (2000). Theory and practice of network-based language teaching. In M. Warschauer \& R. Kern (eds.), Network-based language teaching: Concepts and practice. Cambridge: Cambridge University Press, 1-19.

Kötter, M. (2001). Developing distance learners' interactive competence - Can synchronous audio do the trick? International Journal of Educational Telecommunications 7.4, 327-353.

Kötter, M., L. Shield \& A. Stevens (1999). Real-time audio and email for fluency: Promoting distance language learners' aural and oral skills via the internet. ReCALL $11.2,55-60$.

Kramsch, C. \& S. Thorne (2002). Foreign language learning as global communicative practice. In D. Block \& D. Cameron (eds.), Globalization and language teaching. London: Routledge, 83-100. 
Kym, A. (2004). A hybrid German business course. In I. Thompson \& D. Hiple (eds.), Distance education, distributed learning, and language instruction symposium. Honolulu, HI: University of Hawaii National Foreign Language Resource Center. <http://www.nflrc.hawaii.edu/ networks/nw44/kym.htm $>$ accessed 5/7/2006.

Lamy, M.-N. (2004). Oral conversations online: Redefining oral competence in synchronous environments. ReCALL $16.2,520-538$.

Lamy, M.-N. (2005). Apprenants et conférences électroniques: Facilitation et détournements. In Proceedings of the conference L'institution face au numérique, Séminaire Informatique et Formation. Paris: Maison des Sciences de l'Homme. <http://sif2005.mshparisnord.org/pdf/lamy. pdf $>$ accessed 5/7/2006.

Lamy, M.-N. \& R. Goodfellow (1999a). 'Reflective conversation' in the virtual language classroom. Language Learning and Technology 2.2, 43-61.

Lamy, M.-N. \& R. Goodfellow (1999b). Supporting language students' interactions in web-based conferencing. Computer Assisted Language Learning 12.5, 457-477.

Lamy, M.-N. \& X. Hassan (2003). What influences reflective interaction in distance peer learning? Evidence from four long-term online learners of French. Open Learning 18.1, 39-60.

Laouénan, M. \& S. Stacey (1999). A brief experiment in distance teaching and learning of French. British Journal of Educational Technology 30.2, 177-180.

Laurillard, D. (2003). Foreword. In Felix (ed.), ix-x.

Lewis, T. (2003). Integrating autonomous learning into the curriculum. In Lewis \& Walker (eds.), 169-176.

Lewis, T. \& L. Walker (eds.) (2003). Autonomous language learning in tandem. Sheffield: Academy Electronic Publications.

Little, D. (2003). Imparare le lingue in tandem e autonomia dell'apprendente. In G. Hehmann \& G. Ponti (eds.), Apprendimiento autonomo delle lingue in tandem. Torino: Trauben/Dipartimento di Scienze del Linguaggio e Letterature Moderne e Comparate, Universitate degli Studi di Torino, 21-27.

Möllering, M. (2000). Computer mediated communication: Learning German online in Australia. ReCALL 12.1, 2734

Moore, M. (1993). Theory of transactional distance. In D. Keegan (ed.), Theoretical principles of distance education. New York: Routledge, 22-38.

Murphy, L. (2005a). Attending to form and meaning: The experience of adult distance learners of French, German and Spanish. Language Teaching Research 9.3, 295-327.

Murphy, L. (2005b). Critical reflection and autonomy: A study of distance learners of French, German and Spanish. In Holmberg et al. (eds.), 20-39.

Murray, D. (2000). Protean communication: The language of computer-mediated communication. TESOL Quarterly $34.3,397-421$.

Nicholson, A. (1997). Current practice in the use of telematics to support distance learners in the Adult Migrant English Program. Sydney: National Centre for English Language Teaching and Research (NCELTR), Macquarie University.

Nunan, D. (1999). A foot in the world of ideas: Graduate study through the Internet. Language Learning \& Technology $3.1,52-74$.

O'Dowd, R. \& M. Ritter (2006). Understanding and working with 'Failed Communication' in telecollaborative exchanges. CALICO Journal 23.3, 623-642.

O'Dwyer, J. (1993). Self-study: Empirical research into materials design and use. In Richards \& Roe (eds.), 108 123.

Osler, A. \& H. Starkey (2001). Language learning and antiracism: Some pedagogical. challenges. The Curriculum Journal 12, 313-329.
Otto, E. (2003). Language learning strategies in Tandem: How to learn efficiently. In Lewis \& Walker (eds.), 7992.

Oxford, R., Y. Park-Oh, S. Ito \& M. Sumrall (1993). Factors affecting achievement in a satellite-delivered Japanese language program. The American Journal of Distance Education $7.1,11-25$.

Palloff, R. \& K. Pratt (2001). Lessons from the cyberspace classroom: The realities of online teaching. San Francisco: Jossey-Bass.

Peters, O. (1989). The iceberg has not melted: Further reflections on the concept of industrialisation and distance teaching. Open Learning 4.3, 3-8.

Poon, A. (2003). A challenge for the developer: Issues of interactivity and linguistic-cognitive appropriateness in English language learning. Open Learning 18.2, 135153.

Ramirez, S. \& K. Savage (2001). Closing the distance in adult ESL: Two approaches to video-based learning. In Henrichsen (ed.), 25-38.

Raskin, J. (2001). Using the world wide web as a resource for models and interaction in a writing course. In Henrichsen (ed.), 61-70.

Reynard, R. (2003). Internet-based ESL for distance adult students - A framework for dynamic language learning. The Canadian Modern Language Review 60.2, 123-142.

Richards, K. \& P. Roe (eds.) (1993). Distance learning in ELT. London: Macmillan.

Riel, M. \& L. Harasim (1994). Research perspectives on network learning. Machine-Mediated Learning 42.2\&3, 91113

Robinson, B. (2001). Innovation in open and distance learning: Some lessons from experience and research. In F. Lockwood \& A. Gooley (eds.), Innovation in open and distance learning. London: Kogan Page, 15-26.

Rogers, D. \& A. Wolff (2000). El español ... ia distancia!: Developing a technology-based distance education intermediate Spanish course. Journal of General Education 49.1, 44-52.

Ros i Solé, C. (2003). Culture for beginners: A subjective and realistic approach for adult language learners. Language and Intercultural Communication 3.2, 141-150.

Ros i Solé, C. \& R. Mardomingo (2004). Trayectorias: A new model for online task-based learning. ReCALL 16.1, 145-157.

Ros i Solé, C. \& M. Truman (2005a). Feedback in distance language learning: Current practices and new directions. In Holmberg et al. (eds.), 72-91.

Ros i Solé, C. \& M. Truman (2005b). Feedback in distance learning programmes in languages: Attitudes to linguistic faults and implications for the learning process. Distance Education 26.3, 299-323.

Rothenberg, M. (1998). The new face of distance learning in language instruction. In S. Jager, J. Nerbonne \& A. van Essen (eds.), Language teaching and language technology. Lisse, Netherlands: Swets \& Zeitlinger, 146-148.

Schramm, A. (2005). Making online students connect. In Holmberg et al. (eds.), 230-241.

Selman, M. (1988). Distance education materials: A report from students and teachers. TESL Talk 18.1, 190-199.

Shelley, M. (1999). Fremdsprachen an der Open University: Ihre Entwicklung. Zeitschrift für Interkulturellen Fremdsprachenunterricht $4.1<$ http://www.spz.tu-darmstadt.de/ projekt_ejournal/jg_04_1/beitrag/shelley1.htm $>$ accessed $5 / 7 / 2006$

Shelley, M. \& U. Baumann (2005). Assessing intercultural competence gain in a German distance learning course for adults. In Holmberg et al. (eds.), 119-139.

Shield, L., M. Hauck \& S. Hewer (2001). Talking to strangers - the role of the tutor in developing target language speaking skills at a distance. In A. Kazeroni 


\section{Cynthia White}

(ed.), Proceedings of UNTELE 2000 (vol. 2), 75-84. $<$ http://www.utc.fr/ untele/volume2.pdf> accessed 5/ 7/2006.

Shield, L., M. Hauck \& M. Kötter (2000). Taking the distance out of distance learning. In P. Howarth \& R. Herrington (eds.), EAP Learning Technologies. Leeds: Leeds University Press, 16-27.

Shield, L. \& S. Hewer (1999). A synchronous learning environment to support distance learners. In K. Cameron (ed.), CALL \& the learning community. Exeter: Elm Bank, 379-390.

Spreen, C. (ed.) (2002). New technologies and language learning: Cases in the less commonly taught languages. Honolulu, HI: Second Language Teaching and Curriculum Centre, University of Hawaii.

Stanley, B., R. Sutherland \& S. Valentine (2001). Russian language development and maintenance at a distance: Methodology and technology. Applied Language Learning $12.1,1-30$

Stickler, U. (2004). ' . . a and furthermore I will correct your mistakes' Kulturelle Unterschiede bei der Fehlerkorrektur im Tandem. In H.-J. Krumm \& P. Portmann-Tselikas (Hrsg.) Theorie und Praxis. Österreichische Beiträge zu Deutsch als Fremdsprache. Innsbruck \& Wien: Studienverlag, 79-94.

Strambi, A. \& E. Bouvet (2003). Flexibility and interaction at a distance: A mixed-mode environment for language learning. Language Learning and Technology 7.3, 81-102.

Stringer, M., D. Shale \& M. Abrioux (1982). Language learning at a distance: International comparisons. Teaching at a Distance 21, 52-56.

Tait, A. (2000). Planning student support for open and distance learning. Open Learning 15.3, 287-299.

Thang, S. (2005). Investigating distance learners' perceptions of their English proficiency courses. Open Learning 20.3, 243-256.

Thorpe, M. (1993). Reflective learning at a distance. In M. Valcke \& F. Lockwood (eds.), Research in relation to new developments in distance education materials. Heerlen: Open University of the Netherlands, 41-49.

Thorpe, M. (2001). Evaluating the use of learning technologies. In E. Burge \& M. Haughey (eds.), Using learning technologies: International perspectives on practice. London: Routledge, 125-134.

Tudini, V. (2003). Using native speakers in chat. Language Learning and Technology 7.3, 141-159.

Tudini, V. (2005). Chatlines for beginners: Negotiating conversation at a distance. In Holmberg et al. (eds.), 212229

Tuijnman, A. (1999). Lifelong learning policies in a new technological era. In S. Mitter \& M.-I. Bastos (eds.) Europe and developing countries in the globalised information economy. London: Routledge, 155-167.

Vanijdee, A. (2003). Thai distance English learners and learner autonomy. Open Learning 18.1, 75-84.

Walandouw, H. \& T. Penrose (1993). Technology and infrastructure in a mass open language learning system. In Richards et al. (eds.), 60-71.
Wang, Y. (2004a). Distance language learning: Interactivity and fourth-generation Internet-based videoconferencing. CALICO Journal 21.2, 373-395.

Wang, Y. (2004b). Supporting synchronous distance language learning with desktop videoconferencing. Language Learning and Technology 8.3, 90-121.

Wang, Y. \& C. Sun (2000). Synchronous distance education: Enhancing speaking skills via Internet-based real time technology. In X. Zhou, J. Fong, X. Jia, Y. Kambayashi \& Y. Zhang (eds.), Proceedings of the first international conference on Web information systems engineering. Los Alamitos, CA: IEE Computer Society, 168-172.

Wang, Y. \& C. Sun (2001). Internet-based real time language education: Towards a fourth generation distance education. CALICO Journal 18.3, 539-561.

Warschauer, M. (2000). The changing global economy and the future of English teaching. TESOL Quarterly 34.3, 511535

Warschauer, M., H. Shetzer \& C. Meloni (2000). Internet for English teaching. Alexandria, VA: Teachers of English to Speakers of Other Languages, Inc.

Weasenforth, D., C. Meloni \& S. Biesenbach-Lucas (2005). Learner autonomy and course management software. In Holmberg et al. (eds.), 195-211.

Wedemeyer, C. (1971). Independent study. In R. Deighton (ed.), Encyclopedia of education IV. New York: McMillan, 548-557.

White, C. (1995). Autonomy and strategy use in distance foreign language learning: Research findings. System 23, 207-221.

White, C. (1997). Effects of mode of study on foreign language learning. Distance Education 18.1, 178-196.

White, C. (1999a). Expectations and emergent beliefs of selfinstructed language learners. System 27. 443-457.

White, C. (1999b). The metacognitive knowledge of distance learners. Open Learning 14.3, 37-47.

White, C. (2000). The use of multiple textual forms in distance learning. Journal of Distance Learning 4. 18-46.

White, C. (2003). Language learning in distance education. Cambridge: Cambridge University Press.

White, C. (2005). Towards a learner-based theory of distance language learning: The concept of the learner-context interface. In Holmberg et al. (eds.), 55-71.

White, C., P. Easton \& C. Anderson (2000). Students' perceived value of video in a multimedia language course. Educational Media International 37.3, 167-175.

White, C., L. Murphy, M. Shelley \& U. Baumann (2005). Towards an understanding of tutor attributes and expertise in distance language teaching: Tutor maxims. In T. Evans, P. Smith \& E. Stacey (eds.), Research in Distance Education 6. Geelong, Australia: Deakin University, 83-97.

Williams, S. \& P. Sharma (1988). Language acquisition by distance education: An Australian survey. Distance Education 9.1, 127-146.

Zhao, Y., J. Lei, B. Yan, C. Lai \& H. Tan (2005). What makes the difference? A practical analysis of research on the effectiveness of distance education. Teachers College Record 107.8, 1836-1884. 


\title{
Distance learning of foreign languages
}

\author{
White, Cynthia
}

2006

http://hdl.handle.net/10179/9713

22/04/2023 - Downloaded from MASSEY RESEARCH ONLINE 